\title{
Redox Reaction of Multivalent Ions in Glass Melts
}

\author{
Kidong Kim ${ }^{\dagger}$ \\ Department of Materials Science and Engineering, Kunsan National University, Chunbuk 573-701, Korea
}

(Received January 19, 2015; Accepted February 12, 2015)

\begin{abstract}
The redox reaction $\mathrm{M}^{(\mathrm{x}+\mathrm{n})+}+\frac{n}{2} \mathrm{O}^{-2} \rightleftarrows \mathrm{M}^{\mathrm{x}+}+\frac{n}{4} \mathrm{O}_{2}$ of multivalent ions in glass melts influences the melting process and final properties of the glass including the fining (removal of bubbles), infrared absorption and homogenization of melts, reaction between metal electrodes and melts or refractory and melts, and transmission and color of glass. In this review paper, the redox behaviors that occur frequently in the glass production process are introduced and the square wave voltammetry (SWV) is described in detail as an in situ method of examining the redox behavior of multivalent ions in the melt state. Finally, some voltammetry results for LCD glass melts are reviewed from the practical viewpoint of SWV.
\end{abstract}

Key words : Redox reaction, Multivalent element, Glass melt, Voltammetry

\section{Introduction}

$\mathrm{F}$ or production of glasses, $\mathrm{O}_{2}$ or $\mathrm{SO}_{2}$ generated by reduction of multivalent ions (M) called as a "fining agent" in fining process contributes to removal of bubbles. Such multivalent ions that exist in a minor amount $(<1 \mathrm{wt} \%)$ greatly influence the production processes such as bubble removal, homogenization of glass melts, reactions between metal refractory and glass melts, colors of final glasses, and visible light absorption, etc., including the properties of solid glasses through oxidation/reduction (to be referred to as "redox" hereafter) reactions in the glass melts. Namely, they affect not only characteristics of melt and process but also properties of final glass product. Such multivalent elements are originated from impurities in the raw material (for example, iron oxides are generally present as an impurity in a minor amount in natural raw materials such as silica sand, etc.), materials in contact with glass melts (for example, refractory, molybdenum electrode, etc.) and fining agents, or deliberately added to glasses to provide the glass with particular properties (for example, control of colors or light transmittance).

Therefore, several types of multivalent elements are contained in the commercial glasses, and it is very interesting to directly observe their redox behavior in a molten state. Described in the present review paper are 1) theoretical considerations on redox reactions and influencing factors, 2) redox reaction behavior occurring in production of actual commercial glasses, 3) understanding of square wave voltammetry (commonly abbreviated as SWV), in particular,

${ }^{\dagger}$ Corresponding author : Kidong Kim

E-mail : KdKim@kunsan.ac.kr

Tel : +82-63-469-4737 Fax : +82-63-462-6982 among the voltammetry allowing qualitative/quantitative observation of redox behavior for multivalent ions in a molten state, 4) results of SWV performed for commercial glasses from the aspect of practicality, which have been disclosed in the literature.

\section{Theoretical Considerations on Redox Reactions and Effects on Properties of Glasses}

\subsection{Theoretical considerations ${ }^{1,2)}$}

In multivalent elements (M) doped glass melts, the charge number of a multivalent ion is changed by the following reaction.

$$
\mathrm{M}^{(\mathrm{x}+\mathrm{n})+}+\frac{n}{2} \mathrm{O}^{-2} \rightleftarrows \mathrm{M}^{\mathrm{x}+}+\frac{n}{4} \mathrm{O}_{2}
$$

where $\mathrm{n}$ is the number of electrons accompanying a change in charge states of the multivalent ion, and $\mathrm{O}_{2}$ the physically dissolved oxygen. If the reaction proceeds toward right and the charge number of $\mathrm{M}$ ion decreases, it will be a reduction reaction, whereas it will be an oxidation reaction if the reaction proceeds toward left resulting in increase of the charge number. In a redox reaction of multivalent elements, the equilibrium pressure of oxygen in the glass melt which provides or receives electrons is very important. Ions do not actually exist in one charge number state in melts or glasses, but in the states of $\mathrm{M}^{\mathrm{x}+}$ and $\mathrm{M}^{(\mathrm{x}+\mathrm{n})+}$, where redox ratio between them (i.e., ratio of concentrations for each ion, $\left[M^{x+}\right] /\left[M^{(x+n)+}\right]$, when the above redox reaction has reached an equilibrium state under a given condition) depends on temperature, oxygen equilibrium pressure and glass composition. Therefore, even for glasses of the same composition, redox ratios for a multivalent ion at a high temperature and a low temperature have to be different. When the above redox reaction has reached an equilibrium at temperature 
$\mathrm{T}$, the equilibrium constant $\mathrm{K}(\mathrm{T})$ can be expressed by using the concentrations of ions constituting reactants and products, and oxygen partial pressure or equilibrium pressure as follows.

$$
\mathrm{K}(\mathrm{T})=\frac{\left[M^{x+}\right] \bullet P_{o_{2}}^{n / 4}}{\left[M^{(x+n)+}\right]}
$$

Equilibrium constant at temperature $\mathrm{T}, \mathrm{K}(\mathrm{T})$ or redox ratio $\left(\left[M^{x+}\right] /\left[M^{(x+n)+}\right]\right)$ and oxygen equilibrium pressure $\left(\mathrm{P}_{\mathrm{O} 2}\right)$ can be determined by several methods mentioned in Chapter 3 .

\subsection{Factors influencing redox reactions ${ }^{3)}$}

As briefly mentioned earlier, the factors influencing redox ratio of a multivalent ion, $\left[M^{x+}\right] /\left[M^{(x+n)+}\right]^{\prime}$, can be largely divided into three items.

1) Temperature

With increase of temperatures, it moves to a lower valence, i.e., reduction reaction is dominant, and the value of $\left[M^{x+}\right] /\left[M^{(x+n)+}\right]$ is increased accordingly.

2) Effects of oxygen equilibrium pressure

According to the equation (2), the relationship between redox ratio and oxygen equilibrium pressure within a glass melt is, $\left[M^{x+}\right] /\left[M^{(x+n)+}\right]=\mathrm{KP}_{\mathrm{O}_{2}}^{-\mathrm{n} / 4}$, where $\mathrm{K}$ is the equilibrium constant, and a linear relationship with a slope of $-4 / n$ will be shown when log $\left[M^{x^{+}}\right] /\left[M^{(x+n)+}\right]$ is plotted against $\log \mathrm{P}_{\mathrm{O} 2}$. Here, the slope is -4 if the difference in valence state, i.e., $\mathrm{n}=1$, while the slope becomes -2 if $\mathrm{n}=2$.

3) Glass composition

According to various experimental results, the effects of composition on redox ratio (for example, concentration and types of alkali and alkali earth, types of glass-forming oxides, etc.) are known to clearly exist although their explanation is not theoretically sufficient. Since the non-bridging oxygen produced as a result of introduction of alkali, in particular, acts as free oxygen, the activity of oxygen ions is increased and hence is known to have a considerable effect on redox ratio.

\subsection{Examples for the effect of redox reactions on properties of glass and melt}

2.3.1. Colors of glass and absorption of infrared rays by melt

Final color of a glass depends mainly on redox ratio of the multivalent elements (mainly transition elements) present in the glass. Table 1 contains valence state of the multivalent elements and color of the glass corresponding to this in the visible range for soda lime silicate glass. ${ }^{4)}$ In the case of $\mathrm{Fe}$, for instance, green blue color is exhibited if $\mathrm{Fe}^{2+}$ prevails, while the glass shows yellow color if $\mathrm{Fe}^{3+}$ prevails.

In particular, redox ratios of multivalent ions such as $\mathrm{Fe}$ and $\mathrm{Cr}$ are very important in melts due to their characteristics of infrared ray absorption. Since $\mathrm{Fe}^{2+}$ has a greater absorption of infrared rays with the long wavelength than $\mathrm{Fe}^{3+}$, and $\mathrm{Cr}^{3+}$ than $\mathrm{Cr}^{6+}$, the $\left[\mathrm{Fe}^{2+}\right] /\left[\mathrm{Fe}^{3+}\right]$ or $\left[\mathrm{Cr}^{3+}\right] /\left[\mathrm{Cr}^{6+}\right]$ existing in the melt is very important in a glass melting fur- nace heated by burner flames. As shown in Fig. 1, since the melting runs generally by radiation heat of the combustion space in a continuous melting furnace, temperatures of the lower part of the melt depend strongly on redox state of $\mathrm{Fe}$ or $\mathrm{Cr}$, and since such temperature distributions between the upper and the lower parts induce flow, i.e., convection of the liquid, it also greatly influences homogenization of the melt.

\subsubsection{Bubble removal from glass melt ${ }^{5-7)}$}

Removal of bubbles produced during melting of the raw material by a chemical method, i.e., chemical fining, is achieved basically by redox reaction of multivalent elements. For example, in the case of Sb the primary fining (growth and collapse of bubbles) proceeds by oxygen released at high temperature according to the following redox reaction, while the secondary fining (or refining) with shrinkage and extinction of residual bubbles at low temperature is induced by absorption of oxygen according to the reverse reaction.

$$
\left.\mathrm{Sb}^{5+}(\text { melt })+\mathrm{O}^{2-}(\text { melt }) \rightarrow \mathrm{Sb}^{3+}(\text { melt })+\frac{1}{2} \mathrm{O}_{2} \text { (gas }\right)
$$

Table 1. Charge Number of Various Multivalent Elements and Coloration of Soda Lime Silicate Glass Doped with One of Them ${ }^{4)}$

\begin{tabular}{ccc}
\hline Element & Charge number & Glass color \\
\hline \multirow{2}{*}{$\mathrm{Ti}$} & $\mathrm{Ti}^{3+}$ & Blue \\
& $\mathrm{Ti}^{4+}$ & None \\
\hline \multirow{2}{*}{$\mathrm{V}$} & $\mathrm{V}^{3+}$ & Green \\
& $\mathrm{V}^{4+}$ & Green \\
& $\mathrm{V}^{5+}$ & Deep Yellow Green \\
\hline \multirow{2}{*}{$\mathrm{Cr}$} & $\mathrm{Cr}^{3+}$ & Emerald Green \\
& $\mathrm{Cr}^{6+}$ & Deep Yellow \\
\hline \multirow{2}{*}{$\mathrm{Mn}$} & $\mathrm{Mn}^{2+}$ & Deep Red \\
& $\mathrm{Mn}^{3+}$ & Purple \\
\hline \multirow{2}{*}{$\mathrm{Fe}$} & $\mathrm{Fe}^{2+}$ & Green Blue \\
& $\mathrm{Fe}^{3+}$ & Yellow \\
\hline \multirow{2}{*}{$\mathrm{Mo}$} & $\mathrm{Mo}^{3+}$ & Light Brown \\
& $\mathrm{Mo}^{4+}$ & Green \\
\hline
\end{tabular}

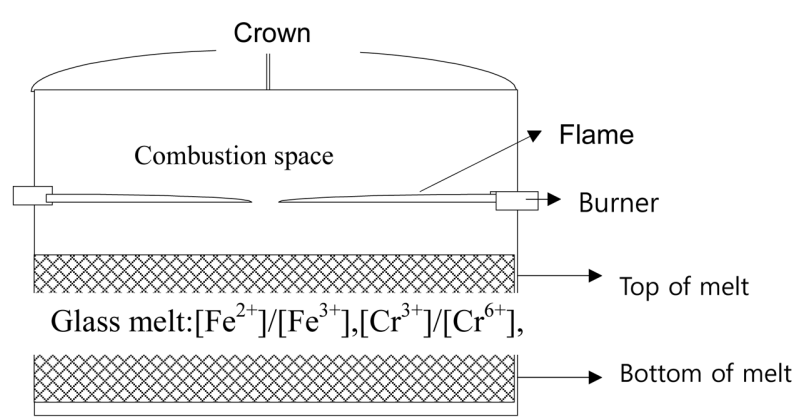

Fig. 1. Combustion space in melting furnace and redox couples affecting temperature difference between bottom and top of glass melt. 
Therefore, redox ratio, $\left[S b^{3+}\right] /\left[S b^{5+}\right]$ of $\mathrm{Sb}$ ions is affected by temperature, oxygen partial pressure and amount of antimony oxide. Sulfate such as $\mathrm{Na}_{2} \mathrm{SO}_{4}$ used as a fining agent in soda lime silicate glass industry acts to remove bubbles by releasing $\mathrm{SO}_{2}$ and $\mathrm{O}_{2}$ at high temperature according to the following redox reaction and subsequently inducing growth of bubbles.

$$
\mathrm{SO}_{4}^{2-}(\text { melt }) \rightarrow \mathrm{SO}_{2} \text { (gas) }+\frac{1}{2} \mathrm{O}_{2}(\text { gas })+\mathrm{O}^{2-}(\text { melt })
$$

\section{Determination of Oxygen Equilibrium Pressure, Redox Ratio or Equilibrium Constant of Melts}

Methods for determining redox ratio and equilibrium constant can be divided into an indirect method and a direct (In situ) method.

\subsection{Measurement of redox reaction in glass state: Indirect method ${ }^{4)}$}

After maintaining an equilibrium for the melt at a given temperature and atmosphere, it is rapidly cooled to room temperature for determination of valence states of a multivalent element by a spectroscopic analysis or a wet chemical analysis. This method involves an indirect measurement of valence states for a multivalent element by using a rapid cooling, and has several disadvantages although it has an advantage of allowing easy determination of valence states at room temperature by using relatively simple experimental equipment. In particular, it has a decisive disadvantage of failing to accurately reflect the actual valence states at a high temperature because the redox ratio of a multivalent element present in the glass is affected by cooling rates, and accurate measurement of each valence state by a wet chemical analysis is impossible when two different multivalent elements coexist. ${ }^{8)}$

\subsection{Examination of redox reaction in the melt state:} In situ method

To exclude the effect of cooling rates mentioned above, direct determination of the equilibrium constant or redox ratio in the molten state at a high temperature is the best method, of which an electrochemical method is representative. The electrochemical method can be applied to many multivalent elements, and is ranked as the most preferred method particularly along with development of excellent oxygen sensors. ${ }^{9,10)}$ Glass melt plays a role as an electrolyte as aqueous solutions, and electrical conduction in a glass occurs by movement of alkali ions such as $\mathrm{Li}^{+}, \mathrm{Na}^{+}, \mathrm{K}^{+}$which can move lightly. Therefore, the electrochemical method which is already being applied to aqueous solutions (to determine ionic concentrations or redox reaction equilibrium) can also be applied to the glass melts. The electrochemical methods are divided again into potentiometric technique and voltammetric technique.
3.2.1. Potentiometric technique ${ }^{11-14)}$

Electrochemical potential differences between two electrodes are simply measured in the condition of electric current being 0 , and such potential differences can be converted to the concentration differences for the particular ions under particular conditions. In glass melts, potentiometric technique is applied to measure the oxygen equilibrium pressure $\left(\mathrm{P}_{\mathrm{O} 2}\right)$. As shown in Fig. 2, two platinum electrodes are employed, of which one electrode is immersed in the glass melt while the other electrode exists in a reference gas (pure air) for which the oxygen partial pressure $\left(P_{r_{2}}: 0.21\right.$ bar) is known. Such reference electrode is connected to an oxygen ion-conducting material $\left(\mathrm{Y}_{2} \mathrm{O}_{3}\right.$ - stabilized $\mathrm{ZrO}_{2}$ oxygen sensor: YSZ) in contact with the melt. If the oxygen equilibrium pressure $\left(\mathrm{P}_{O 2}\right)$ of the melt at a temperature $\mathrm{T}$ is different from the oxygen partial pressure $\left(P_{\mathrm{rO}_{2}}\right)$ of the reference gas, potential difference $\left(\mathrm{E}_{\mathrm{m}}\right)$ occurs between two electrodes, which is expressed by Nernst equation as follows.

$$
\mathrm{E}_{\mathrm{m}}=\frac{R_{\mathrm{g}} \bullet T}{4 F} \ln \frac{P_{O 2}}{P_{r O 2}}
$$

where $\mathrm{R}_{\mathrm{g}}$ : gas constant, F: Faraday constant. Therefore, the oxygen equilibrium pressure of the melt at a temperature $\mathrm{T}$ is given by the following equation.

$$
\mathrm{P}_{\mathrm{O} 2}=P_{r O 2} \cdot \exp \left[\frac{4 \cdot F \cdot E_{m}}{R_{g} \cdot T}\right]
$$

Redox reaction equilibrium constant $\mathrm{K}$, Enthalpy $\left(\Delta \mathrm{H}^{0}\right)$ and Entropy $\left(\Delta S^{0}\right)$ are calculated by using the following equation (7) which is derived from the use of the equation (2) and the relationship of $\Delta \mathrm{G}^{0}=\Delta \mathrm{H}^{0}-\mathrm{T} \Delta \mathrm{S}^{0}=-\mathrm{R}_{\mathrm{g}} \mathrm{T} \operatorname{lnK}$.

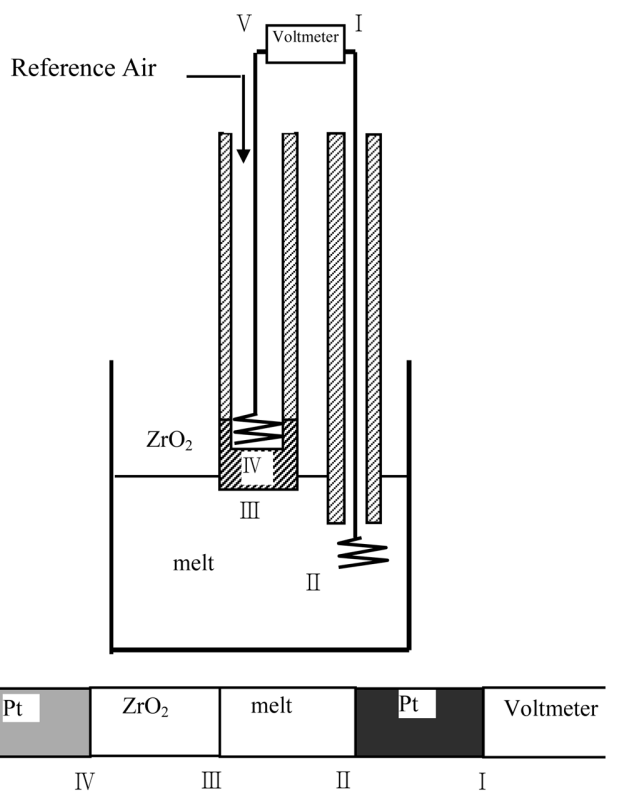

Fig. 2. Experimental cell for determination of oxygen equilibrium pressure by potentiometric technique. 


$$
\mathrm{K}(\mathrm{T})=\frac{\left[M^{x+}\right] \bullet P_{O 2}^{n / 4}}{M^{(x+n)+}}=\exp \left\{\frac{-\Delta \mathrm{H}^{0}}{R_{g} T}+\frac{\Delta \mathrm{S}^{0}}{R_{g}}\right\}
$$

After concentrations, $\left[\mathrm{M}^{\mathrm{x}}\right]$ and $\left[\mathrm{M}^{(\mathrm{x}+\mathrm{n})+}\right]$ at a temperature $\mathrm{T}$ are determined for the rapidly cooled glass by a spectroscopic or a wet chemical analysis, the equilibrium constant $\mathrm{K}(\mathrm{T})$ is determined by substituting the oxygen equilibrium pressure $\left(\mathrm{P}_{O 2}\right)$ of the melt corresponding to the temperature $\mathrm{T}$ in the above equation. However, there is a problem that the concentrations of $\mathrm{M}^{\mathrm{x}+}$ and $\mathrm{M}^{(\mathrm{x}+\mathrm{n})+}$ obtained from the quenched glass fails to reflect actual concentrations at a high temperature, since redox ratio of a multivalent ion depends not only on cooling rates but also on temperatures as mentioned in 3.1.

Although the experimental cells with a configuration of Fig. 2 have been commercially developed into large-scale cells in 1990's, and applied as a means for process control that directly and continuously tracks oxidation states of the melt by installation in a forehearth of the glass production process, their efficacy has not been verified yet. ${ }^{15-20)}$

\subsubsection{Voltammetry technique $\mathrm{e}^{21-41)}$}

The voltammetry technique enables to identify not only oxygen equilibrium pressure $\left(\mathrm{P}_{\mathrm{O} 2}\right)$ of the melt but also concrete redox behavior such as redox ratio of multivalent ions, while the experimental cell is comprised of 3 electrodes of working electrode $(\mathrm{Pt})$, reference electrode $\left(\mathrm{ZrO}_{2}+\mathrm{Pt}\right)$ and counter electrode $(\mathrm{Pt})$ as shown in Fig. 3.

Unlike potentiometric technique where potential differ-

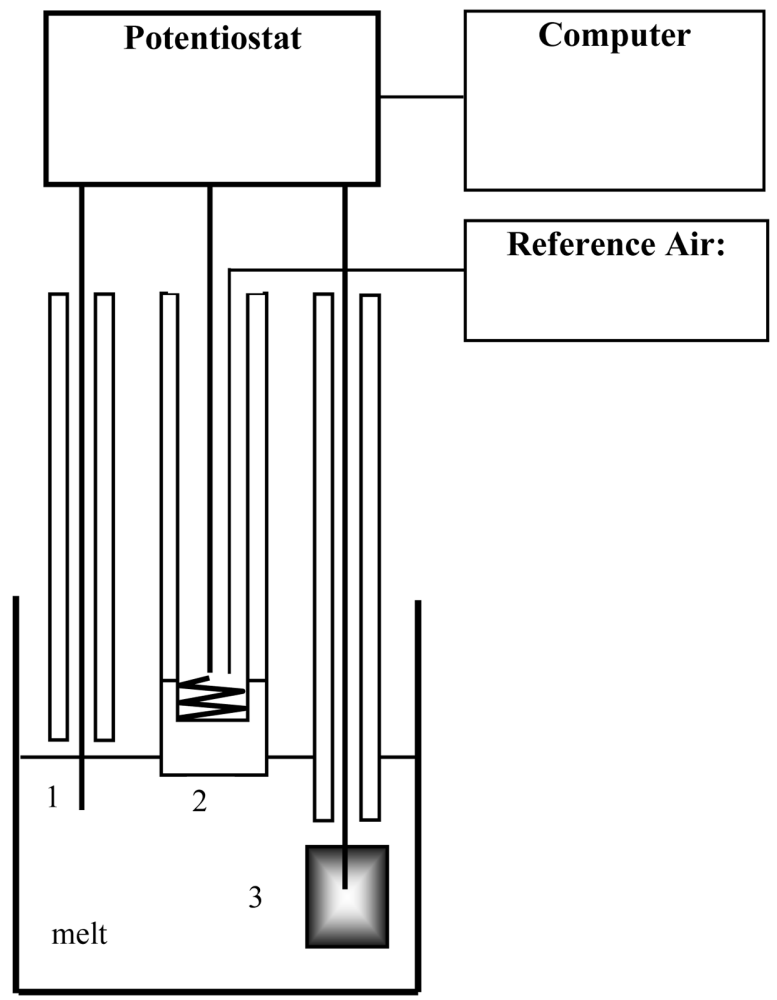

Fig. 3. Experimental voltammetry cell, 1: working electrode, 2: reference electrode, 3: counter electrode. ences between electrodes of the working and the reference are passively measured by a voltmeter, currents in voltammetric technique can flow between the working electrode and the counter electrode through potentiostat, namely by actively applying a given potential difference to the glass melt as an electrolyte as shown in the schematic circuit diagram of Fig. 4. If the applied potential difference is sufficient to allow donation and acceptance of electrons, the flowing current can be considered to be caused by redox reaction, which is called the Faradaic current in such case. Currents flowing in the circuit are measured as a function of potential differences applied between the working electrode and the reference electrode, while current-potential curve obtained from such results is called the voltammogram, where oxidation-reduction reaction occurring at the electrodes is eventually reflected. In such current-potential curve, i.e., votammogram, characteristic peaks due to reduction of multivalent ions (usually indicated by $\mathrm{M}^{(\mathrm{x}+\mathrm{n})+} / \mathrm{M}^{\mathrm{x}}$ ) appear, and a form of the curve is dependent on concentration, tempetature, diffusion coefficient of the multivalent ions participating in redox reaction, surface area of the working electrode immersed in the glass melt, scan rate (V/ sec) of the potential differences applied between the working electrode and the reference electrode, and frequency, etc. According to the literature, voltammetric technique is divided into cyclic voltammetry $(\mathrm{CV})^{21,22)}$ where triangular waves are employed depending on potential-time dependence applied and wave form, and square wave voltammetry (SWV) where rectangular waves are employed ${ }^{23-41)}$, while the SWV method is known to be exceedingly superior in the resultant sensitivity and resolution of voltammogram. ${ }^{23,24)}$ Consequently, SWV is the most excellent electrochemical method at present, by which redox reactions can be quantitatively studied in the glass area. However, applicable potential domains are limited approximately to a range between 0 and $-800 \mathrm{mV}$ because of oxygen gas formation at the working electrode and dissolution of platinum electrode

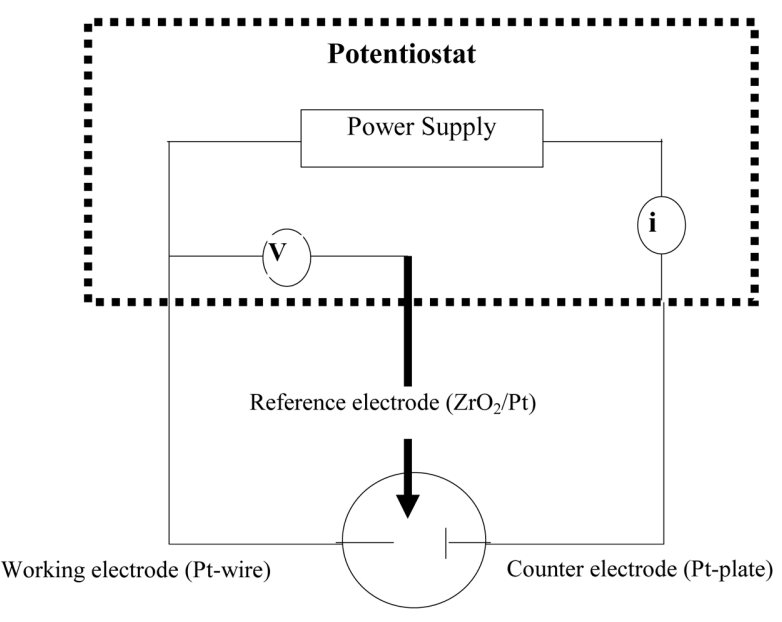

Three electrode cell

Fig. 4. Circuit diagram of voltammetry cell. 
in domain of positive potential application, and reduction of glass-forming oxides such as $\mathrm{SiO}_{2}$ occurring in the low negative potential domain.

Figure 5 is a typical votammogram obtained by SWV method, representing the result $\left(\mathrm{d}_{\mathrm{i}}=\mathrm{i}_{\mathrm{f}}-\mathrm{i}_{\mathrm{r}}\right)$ where the reverse current ( $\mathrm{i}_{\mathrm{r}}$ : current produced as a result of a potential applied in the direction from $-800 \mathrm{mV}$ to $0 \mathrm{~V}$ ) is subtracted from the forward current ( $i_{\mathrm{f}}$ : current produced as a result of a potential applied in the direction from $0 \mathrm{~V}$ to $-800 \mathrm{mV}$ ). In the voltammogram, peak potential $\left(\mathrm{E}_{\mathrm{p}}\right)$ showing the maximum value of current, i.e., peak current $\left(\mathrm{I}_{\mathrm{p}}\right)$ refers to a stage where $\mathrm{M}^{(\mathrm{x}+\mathrm{n})+}$ accepts $\mathrm{n}$ electrons from the working electrode for reduction to $\mathrm{M}^{\mathrm{x}+}\left(\mathrm{M}^{(\mathrm{x}+\mathrm{n})+} / \mathrm{M}^{\mathrm{x}+}\right)$,

$$
\mathrm{M}^{(\mathrm{x}+\mathrm{n})+}+\mathrm{ne}^{-} \rightarrow \mathrm{M}^{\mathrm{x}+}
$$

At counter electrode, $\mathrm{O}^{2-}$ existing in the glass melt releases electrons and is oxidized to $\mathrm{O}_{2}$

$$
\mathrm{O}_{2}+4 \mathrm{e}^{-} \leftarrow 2 \mathrm{O}^{2-}
$$

As a result, whole reaction becomes as shown in the following equation.

$$
\mathrm{M}^{(\mathrm{x}+\mathrm{n})+}+\frac{n}{2} \mathrm{O}^{-2} \rightleftarrows \mathrm{M}^{\mathrm{x}+}+\frac{n}{4} \mathrm{O}_{2}
$$

By substituting the activity of each ion with the concentration, redox reaction equilibrium constant $\mathrm{K}$ can be expressed as follows.

$$
\mathrm{K}(\mathrm{T})=\frac{\left[M^{x+}\right] \bullet P_{O 2}^{n / 4}}{\left[M^{(x+n)+}\right]}=\exp \left[\frac{n \cdot F \cdot E_{p}}{R_{g} \cdot T}\right]=\exp \left\{\frac{-\Delta \mathrm{H}^{0}}{\mathrm{R}_{\mathrm{g}} \mathrm{T}}+\frac{\Delta \mathrm{S}^{0}}{\mathrm{R}_{\mathrm{g}}}\right\}
$$

$P_{O 2}^{n / 4}$ at the working electrode is calculated by measuring potential difference $\mathrm{E}_{\mathrm{m}}$ mentioned in 3.2.1, and substituting

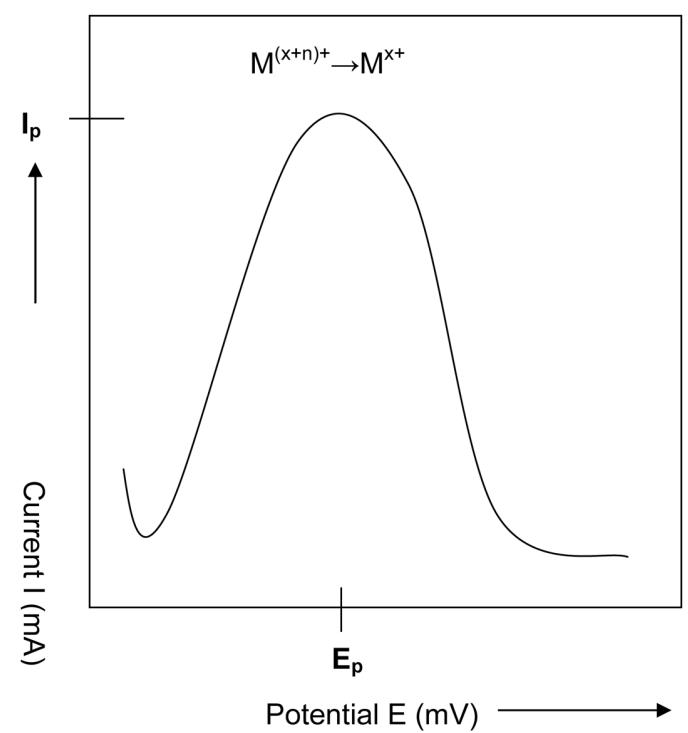

Fig. 5. Typical voltammogram (current-potential curve) by SWV. it in the equation (6). Thus, redox ratio, $\left[M^{x+}\right] /\left[M^{(\mathrm{x}+\mathrm{n})+}\right]$, at the working electrode can be calculated by using the equation (8), while $\Delta \mathrm{H}^{0}$ and $\Delta \mathrm{S}^{0}$ can also be calculated by using the peak potential $\left(\mathrm{E}_{\mathrm{P}}\right)$ and the linear relationship with $\mathrm{T}$.

Since peak current, $I_{p}$, is proportional to the overall concentration $\left(\mathrm{C}_{\mathrm{o}}\right)$ of multivalent ions and the area $(\mathrm{A})$ of the working electrode, it can be represented as in the following equation.

$$
\mathrm{I}_{\mathrm{p}}=\mathrm{K}_{\mathrm{I}} \mathrm{C}_{\mathrm{o}} \mathrm{A}
$$

And $\mathrm{K}_{\mathrm{I}}$ is a constant, $\mathrm{K}_{\mathrm{I}}=\frac{n^{2} \cdot F^{2} \bullet D^{1 / 2} \bullet \Delta E \bullet \mathrm{a}}{R \bullet T \bullet \tau^{1 / 2}}$, where $\mathrm{D}$ : diffusion coefficient of a multivalent ion, $\Delta \mathrm{E}$ : step potential, a: $0.31, \mathrm{~T}$ : absolute temperature, $\tau$. reciprocal of frequency (pulse time)

$$
\mathrm{I}_{\mathrm{p}}=\mathrm{C}_{\mathrm{o}} \mathrm{A} \frac{n^{2} \cdot F^{2} \cdot D^{1 / 2} \cdot \Delta E \bullet \mathrm{a}}{R \cdot T \cdot \tau^{1 / 2}}
$$

Therefore, the diffusion coefficient $\mathrm{D}$ of a multivalent ion at a temperature $\mathrm{T}$ can be calculated by using the linear relationship between $\mathrm{I}_{\mathrm{p}}$ and $\tau^{-1 / 2}$ as shown in Fig. 6 .

\section{SWV Performed for Some Commercial Glasses}

There have been some publications on redox behavior of a few multivalent ions with melts by using voltammetry method in 1980's, ${ }^{21-25)}$ and numerous papers by SWV have been continuously published in Europe for the past 25 years coming into 1990's, which considered redox behavior of various multivalent ions, i.e., reaction equilibrium constant, thermodynamics data such as enthalpy and entropy, diffusion coefficient of multivalent ions and effects of temperature, frequency for a variety of glasses such as soda-limesilica and alkali- alumino-borosilicate based glasses etc. ${ }^{26-41)}$ Meanwhile, SWV studies have been conducted in my laboratory since 2006 , with only commercial glasses such as

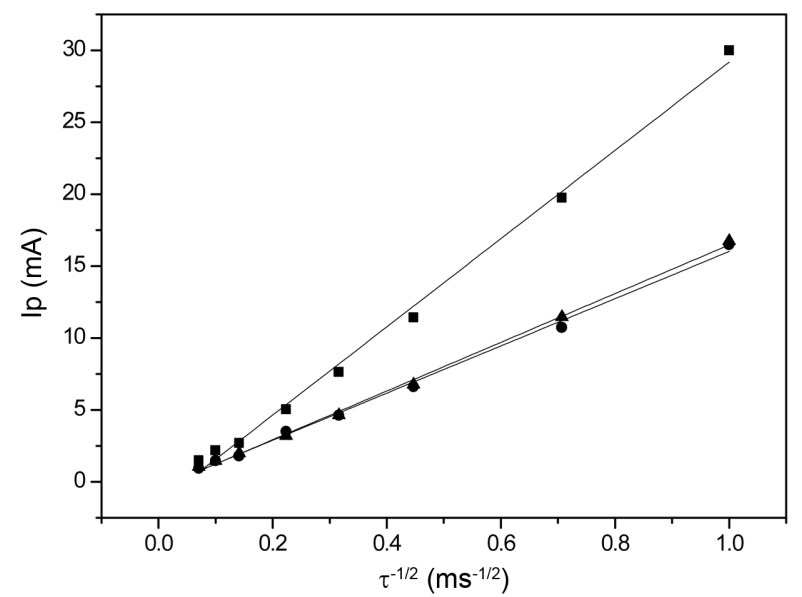

Fig. 6. Peak current $(I)$ as a function of $\tau^{-1 / 2}$ at $1300^{\circ} \mathrm{C}$ for the melts with $\mathrm{K}_{2} \mathrm{O} /\left(\mathrm{Na}_{2} \mathrm{O}+\mathrm{K}_{2} \mathrm{O}\right)=0.25(\boldsymbol{\bullet}), 0.5(\bullet)$ and $0.75(\mathbf{\Delta})^{52)}$. 
alkali-alkaline earth-silica-based CRT glasses, ${ }^{42-47)}$ Flint white glasses, ${ }^{48,49)}$ PDP glasses, ${ }^{50-52)}$ LCD glass ${ }^{53)}$. In those studies, SWV for melts has been attempted by thermodynamic approach to redox equilibrium reactions of multivalent elements and kinetic considerations such as diffusion of multivalent ions. Subsequently some studies $^{54,55)}$ for LCD glass melts have been carried out from the practical viewpoint of SWV in the glass industry and their results are introduced as follows.

\subsection{Fining agent, $\mathrm{SnO}_{2}$ and $\mathrm{As}_{2} \mathrm{O}_{5}^{54)}$}

Although $\mathrm{As}_{2} \mathrm{O}_{5}$ had been used as a fining agent in LCD glass industry, it has been replaced by eco-friendly materials such as $\mathrm{SnO}_{2}$ since about 2010 as a result of concerns on environmental contamination due to the occurrence of LCD waste glasses containing toxic $\mathrm{As}_{2} \mathrm{O}_{5}$ along with disposal of end-of-life LCD panels. However, in bubble removal behavior, there have been no systematic studies as to what specific differences exist between two components, and what component is truly advantageous to bubble removal. Consequently, redox behavior of $\mathrm{As}_{2} \mathrm{O}_{5}$ and $\mathrm{SnO}_{2}$ was directly identified at a high temperature for LCD glass melts by applying the SWV technique, and the voltammetry results were compared with the fining ability of the LCD glass batches to elucidate differences between the two components.

Figure 7 shows a temperature-dependence for $\%$ contents of $\mathrm{Sn}^{2+}, \mathrm{As}^{3+}$ obtained by substituting in the equation (9) of the $\mathrm{E}_{\mathrm{P}}$ caused by $\mathrm{Sn}^{4+} / \mathrm{Sn}^{2+}$ and $\mathrm{As}^{5+} / \mathrm{As}^{3+}$ shown in the voltammogram of LCD glass melts containing $0.4 \mathrm{SnO}_{2}$, $0.2 \mathrm{As}_{2} \mathrm{O}_{5}$ under the assumption that the melt is equilibrated with air. $\mathrm{As}^{3+}(\boldsymbol{\square})$ is shown to be $60 \%$ at $1600^{\circ} \mathrm{C}$, and is reduced to $22 \%$ at $1300^{\circ} \mathrm{C} . \mathrm{Sn}^{2+}(\mathbf{O})$ is shown to be $67 \%$ at $1600^{\circ} \mathrm{C}$, and is reduced to $30 \%$ at $1300^{\circ} \mathrm{C}$. Redox ratios, i.e.,

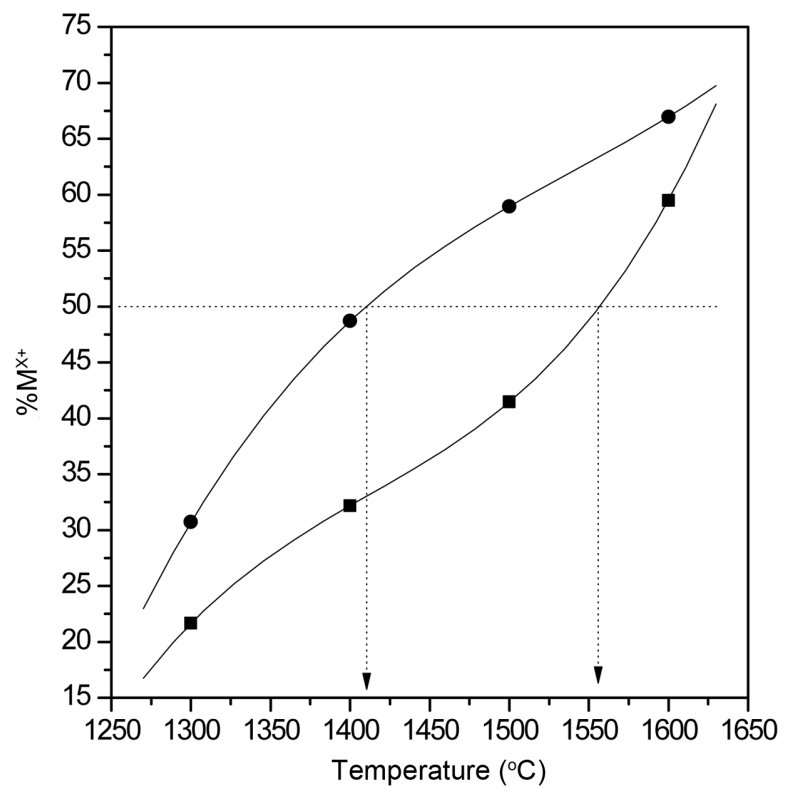

Fig. 7. Temperature dependence of $\% \mathrm{As}^{3+}(\boldsymbol{\square})$ in As-melt and $\% \mathrm{Sn}^{2+}(\mathbf{O})$ in Sn-melt ${ }^{54)}$. the values converted to $\left[\mathrm{As}^{3+}\right] /\left[\mathrm{As}^{5+}\right]$ and $\left[\mathrm{Sn}^{2+}\right] /\left[\mathrm{Sn}^{4+}\right]$, in the range of $1600 \sim 1300^{\circ} \mathrm{C}$ are shown to be $1.467 \sim 0.276$ and $2.025 \sim 0.417$, respectively. Since $\mathrm{E}_{\mathrm{P}}$ of As is smaller than $\mathrm{E}_{\mathrm{P}}$ of $\mathrm{Sn}$ at a given temperature, redox ratio of As is always smaller than that of Sn. Here, according to the dotted line showing the temperature reaching an equilibrium of $\left[\mathrm{M}^{\mathrm{x}}\right] /$ $\left[\mathrm{M}^{\mathrm{x}+\mathrm{n}}\right]=1$ or $\% \mathrm{M}^{\mathrm{x}+}=50$, As-doped melt indicates $1550^{\circ} \mathrm{C}$, while Sn-doped melt indicates $1420^{\circ} \mathrm{C}$. Namely, below this temperature, it means that the volume of $\mathrm{O}_{2}$ absorbed in the glass melt by oxidation of $\mathrm{As}^{3+}$ or $\mathrm{Sn}^{2+}$ shows a positive value. Such temperatures mean that a considerably large amount of oxygen is already absorbed into As-doped melt at an early stage of the secondary fining, whereas oxygen absorption is begun at an intermediate stage of the secondary fining in the case of Sn-doped melt. According to the results of fining experiments conducted by using actual LCD glass batches, fining ability of the As-doped melt is more excellent than that of the Sn-doped melt, and such results are caused by early oxidation of $\mathrm{As}^{3+}$ in the secondary fining region mentioned above. In addition, large bubbles which always appear in the Sn-doped melt after fining experiment demonstrate late oxidation of $\mathrm{Sn}^{2+}$ in the secondary fining region.

\subsection{Oxidizing agent ${ }^{55)}$}

Since industrial glass batches are generally contaminated by various types of carbonaceous materials such as plastic, paper, wood, etc., the fining agent, $\mathrm{M}^{\mathrm{x}+\mathrm{n}}$ is considerably reduced already in a combustion process of such contaminants during the heating process of batches and thus fining efficiency could be decreased in the primary fining. Therefore, a small amount of nitrate (oxidizing agent) is added to oxidize such carbonaceous materials. In the case of LCD glass industry, an oxidizing agent of $\operatorname{Sr}\left(\mathrm{NO}_{3}\right)_{2}$ is introduced in addition to the fining agent $\mathrm{SnO}_{2}$, playing a role of oxygen provider to oxidize carbonaceous materials by the following reaction.

$\mathrm{Sr}\left(\mathrm{NO}_{3}\right)_{2} \rightarrow \mathrm{SrO}+\mathrm{N}_{2}+5 / 2 \mathrm{O}_{2}:$ Reduction
Carbonaceous materials $+\mathrm{O}_{2} \rightarrow$

$\mathrm{CO}_{2}$ : Oxidation/combustion

Despite the actual industrial batches contain almost no carbonaceous materials, if $\operatorname{Sr}\left(\mathrm{NO}_{3}\right)_{2}$ is added to the batch, what effects do the oxygen produced by decomposition of $\mathrm{Sr}\left(\mathrm{NO}_{3}\right)_{2}$ have on redox reaction of $\mathrm{Sn}^{4+}+\mathrm{O}^{-2} \rightleftarrows \mathrm{Sn}^{2+}+1 /$ $2 \mathrm{O}_{2}$ ? Since $\mathrm{NO}_{\mathrm{x}}$ produced by decomposition of $\operatorname{Sr}\left(\mathrm{NO}_{3}\right)_{2}$ induces pollution of atmosphere and is a greenhouse gas, what extent of the amount is suitable? To confirm its contribution to fining and its appropriate amount as oxidizing agent, redox behavior resulting from addition of $\operatorname{Sr}\left(\mathrm{NO}_{3}\right)_{2}$ has been investigated by the SWV.

Figure 8 shows voltammograms at different temperatures of LCD glass melts doped with $\mathrm{SnO}_{2}$ and $\mathrm{SnO}_{2}+\mathrm{Sr}\left(\mathrm{NO}_{3}\right)_{2}$, while Fig. 9 exhibits $\mathrm{E}_{\mathrm{P}}$ due to $\mathrm{Sn}^{4+} / \mathrm{Sn}^{2+}$ shown in the voltammogram of Fig. 8 as a function of amounts of $\operatorname{Sr}\left(\mathrm{NO}_{3}\right)_{2}$. 

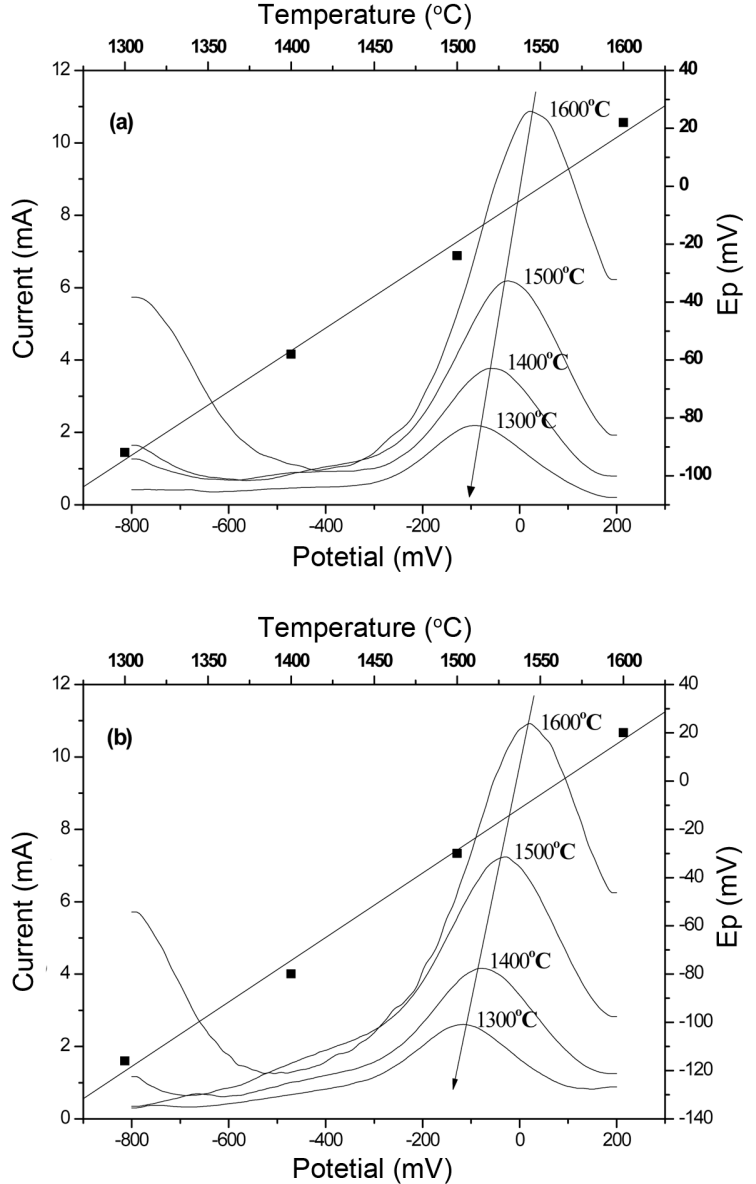

Fig. 8. Voltammogram recorded in (a) normal and (b) 3wt\% nitrate melt containing $0.2 \mathrm{~mol} \% \mathrm{SnO}_{2}$ and temperature dependence of $\mathrm{E}_{\mathrm{p}}(\mathbf{\square})^{55)}$.

Based on the same temperature, addition of $\mathrm{Sr}\left(\mathrm{NO}_{3}\right)_{2}$ induces a decrease in $\mathrm{E}_{\mathrm{p}}$, and hence the oxidizing agent makes redox reaction of $\mathrm{Sn}$ to move to the oxidizing state so that concentrations of $\mathrm{Sn}^{4+}$ in the glass melt are increased. Therefore, a large amount of oxygen production is expected to occur in the reduction process from $\mathrm{Sn}^{4+}$ to $\mathrm{Sn}^{2+}$, and hence an excellent fining ability is predicted. However, $\mathrm{E}_{\mathrm{P}}$ moves in the positive direction, i.e., reduction direction, when the amount of $\mathrm{Sr}\left(\mathrm{NO}_{3}\right)_{2}$ exceeds $3 \mathrm{wt} \%$. When such result for $\mathrm{E}_{\mathrm{p}}$ is compared with the fining ability evaluated by using actual glass batches, the most excellent fining ability is shown at the amount of $\operatorname{Sr}\left(\mathrm{NO}_{3}\right)_{2}$ of $3 \mathrm{wt} \%$, and inverse effects occur as a result of bubble formation due to excess oxygen exceeding the oxygen solubility of the glass melt when more than that is added. Therefore, the positive effects of $\operatorname{Sr}\left(\mathrm{NO}_{3}\right)_{2}$ on fining are possible only within $3 \mathrm{wt} \%$, the reason for which may be explained by the change in $\mathrm{E}_{\mathrm{P}}$ due to $\mathrm{Sn}^{4+} / \mathrm{Sn}^{2+}$ of Fig. 9. In addition, such results mean the existence of an optimal amount in addition of the oxidizing agent to glass batch.

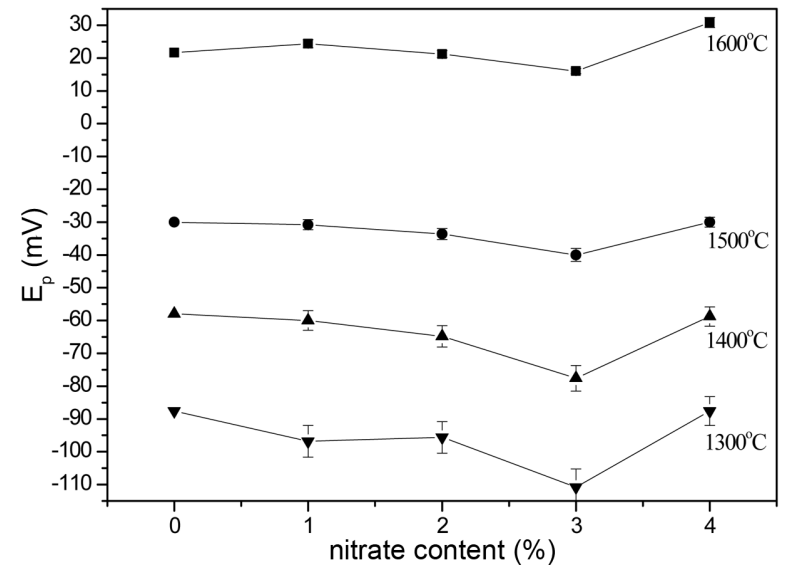

Fig. 9. Dependence of peak potential $\left(\mathrm{E}_{\mathrm{p}}\right)$ on nitrate content at various temperatures ${ }^{55)}$

\section{Conclusion}

Redox states of multivalent ions are influenced greatly in molten states of a glass. In the past three decades, dependence on temperature, frequency and composition of redox behavior for various multivalent ions has been examined by SWV for a variety of silicate and borosilicate melts as well as commercial model melts. Based on those results, thermodynamics data and diffusion coefficients, etc. have been presented for redox reactions of multivalent ions at a high temperature, while fining behavior for a few commercial model melts has been investigated. However, all studies so far have dealt with glasses doped with only one multivalent element. Since actual glasses contain more than two multivalent elements from an industrial viewpoint and mutual redox reactions occur between them, systematic investigations on their mutual reactions for several multivalent element pairs by the SWV will be needed in the future. In addition, if the SWV is applied to researches related with the glass production conducted in the industry, it will be very desirable in practical aspects.

\section{Acknowledgments}

This work was supported by the National Research Foundation of Korea (NRF) and a grant from the Korean government (MEST) (NRF2012R1A1B6001115).

\section{REFERENCES}

1. A. W. M. Wondergem-de Best, "Redox Behaviour and Fining of Molten Glass," pp. 5-20, in Ph.D. Thesis, Technical University Eindhoven, Eindhoven, 1994.

2. H. Bach, F. G. K. Baucke, and D. Krause, Electrochemistry of Glasses and Glass Melts, Including Glass Electrodes; pp. 269-89, Springer-Verlag, Berlin, Heidelberg, 2001.

3. A. Paul, Chemistry of Glasses, $2^{\text {nd }}$ Ed. pp. 219-45, Chapman and Hall, London, New York, 1990. 
4. C. R. Bamford, Color Generation and Control in Glass; pp. 77-86, Elsevier Scientific Publishing Co., Amsterdam, Oxford, New York, 1977.

5. J. Hlavac, Glass Science and Technology, Vol. 4, The Technology of Glass and Ceramics, An Introduction; pp. 111-19, Elsevier Scientific Publishing Co., Amsterdam, Oxford, New York, 1983.

6. E. L. Swarts, Gases in Glass. Proceedings of the 46th Conference on Glass Problems, pp. 62-75, Urbana (USA) 1985. Ed. by C. G. Bergeron, The American Ceramic Society, 1986.

7. F. E. Woolley, Melting/fining, Engineered Materials Handbook; Vol. 4, Ceramics and Glasses, pp. 386-93, The Materials Information Society, ASM Internatinal, 1992.

8. O. Corumluoglu and E. Guadagnino, "Determination of Ferrous Iron and Total Iron in Glass by a Colorimetric Method," Glass Technol., 40 [1] 24-8 (1999).

9. T. Tran and M. P. Brungs, "Application of Oxygen Electrodes in Glass Melts, Part 1. Oxygen Reference Electrode," Phys. Chem. Glasses, 21 [4] 133-40 (1980).

10. C. Rüssel, R. Kohl, and H. Schäffer, "Interaction Between Oxygen Activity of $\mathrm{Fe}_{2} \mathrm{O}_{3}$ Doped Soda-lime-silica Glass Melts and Physically Dissolved Oxygen," Glastech. Ber., 61 [8] 209-13 (1988).

11. O. Lafroukhi, J. Hertz, J. P. Hilger, and G. Cornier, "Electrochemical Measurement of Oxygen Activity in Lead Glass by Means of a Stabilized $\mathrm{ZrO}_{2}$ Sensor, Part 2. Determination of the Equilibrium Constants in the Redox Systems Arsenic and Antimony," Glastech. Ber., 64 [11] 281-90 (1991).

12. J. P. Hilger and O. Lafroukhi, "Electrochemical Measurement of Oxygen Activity in Lead Glass by Means of a Stabilized $\mathrm{ZrO}_{2}$ Sensor, Part 3. Measurement of the Diffusion Coefficient of Oxygen," Glastech. Ber., 64 [12] 299-304 (1991).

13. T. Hayashi and W. G. Dorfeld, "Electrochemical Study of $\mathrm{As}^{3+} / \mathrm{As}^{5+}$ Equilibrium in a Barium Borosilicate Glass Melt," J. Non-Cryst. Solids, 177 331-39 (1994).

14. M. Yamashita and H. Yamanaka, "Oxygen Activity Change in Soda-lime-silica Glass Melts with or without Refining Agent," Glastech. Ber. Glass Sci. Technol., 70 [12] 371-74 (1997).

15. F. G. K. Baucke, "Electrochemical Cells for On-line Measurements of Oxygen Fugacities in Glass-forming Melts," Glastech. Ber., 61 [4] 87-90 (1988).

16. H. Müller-Simon and K. W. Mergler, "Electrochemical Measurement of Oxygen Activity of Glass Melts in Glass Melting Furnaces," Glastech. Ber., 61 [10] 293-99 (1988).

17. M. Zink, C. Rüssel, H. Müller-Simon, and K. W. Mergler, "Voltammetric Sensor for Glass Tanks," Glastech. Ber. Glass Sci. Technol., 65 [2] 25-31 (1992).

18. H. Müller-Simon and K. W. Mergler, "On-line Determination of the Iron Concentration in Industrial Amber Glass Melts," Glastech. Ber. Glass Sci. Technol., 68 [9] 273-77 (1995).

19. F. G. K. Baucke, R. D. Werner, H. Müller-Simon, and K. W. Mergler, "Application of Oxygen Sensors in Industrial Glass Melting Tanks," Glastech. Ber. Glass Sci. Technol., 69 [3] 57-63 (1996).
20. H. Müller-Simon, "Temperature Dependence of the Redox State of Iron and Sulfur in Amber Glass Melts," Glastech. Ber. Glass Sci. Technol., 70 [12] 389-91 (1997).

21. K. Takahashi and Y. Miura, "Electrochemical Studies on Diffusion and Redox Behavior of Various Metal Ions in Some Molten Glasses," J. Non-Cryst. Solids, 38 \& 39 52732 (1980)

22. K. Takahashi and Y. Miura, "Electrochemical Studies on Ionic Behavior in Molten Glasses," J. Non-Cryst. Solids, 80 11-9 (1986).

23. E. Fruede and C. Rüssel, "Voltammetric Methods for Determining Polyvalent Ions in Glass Melts," Glastech. Ber., 60 [6] 201-04 (1987).

24. C. Montel, C. Rüssel, and E. Freude, "Square-wave Voltammetry as a Method for the Quantitative In-situ Determination of Polyvalent Elements in Molten Glass," Glastech. Ber., 61 [3] 59-63 (1988).

25. C. Rüssel and E. Freude, "Voltammetric Studies of the Redox Behaviour of Various Multivalent Ions in Soda-lime-silica Glass Melts," Phys. Chem. Glasses, 30 [2] 62-8 (1989).

26. C. Rüssel and E. Freude, "Voltammetric Studies in a Sodalime-silica Glass Melt Containing Two Different Polyvalent Ions," Glastech. Ber., 63 [6] 149-53 (1990).

27. E. Freude and C. Rüssel, "Iron in Glass Melts - A Voltammetric Investigation," Glastech. Ber., 63 193-97 (1990).

28. T. Kordon, C. Rüssel, and E. Freude, "Voltammetric Investigations in $\mathrm{Na}_{2} \mathrm{SO}_{4}$-refined Soda-lime-silica Glass Melts," Glastech. Ber., 63 [8] 213-18 (1990).

29. C. Rüssel, "The Electrochemical Behavior of Some Polyvalent Elements in a Soda-lime-silica Glass Melts," J. NonCryst. Solids, 119 303-09 (1990).

30. C. Rüssel and G. Sprachmann, "Electrochemical Methods for Investigations in Molten Glass, Illustrated at Iron- and Arsenic-doped Soda-lime Silica Glass Melts," J. Non-Cryst. Solids, 127 197-206 (1991).

31. O. Claußen and C. Rüssel, "Quantitative In-situ Determination of Iron in a Soda-lime-silica Glass Melt with the Aid of Square-wave Voltammetry," Glastech. Ber., 69 [4] 95-100 (1996).

32. C. Rüssel, "EPR and Voltammetric Studies of Iron-containing Mixed Alkali Glasses with the Basic Composition $\mathrm{xNa}_{2} \mathrm{O}(16-\mathrm{x}) \mathrm{K}_{2} \mathrm{O} 10 \mathrm{CaO} 74 \mathrm{SiO}_{2}, "$ Glastech. Ber. Glass Sci. Technol., 70 17-22 (1997).

33. O. Claußen and C. Rüssel, "Voltammetry in a Sulfur and Iron-containing Soda-lime-silica Glass Melt," Glastech. Ber. Glass Sci. Technol., 70 231-37 (1997).

34. O. Claußen and C. Rüssel, "Thermodynamics of Some Transition Metal Ions in a Borosilicate Glass Melt," Phys. Chem. Glasses, 38 227-31 (1997).

35. A. Matthai, D. Ehrt, and C. Rüssel, "Redox Behavior of Polyvalent Ions in Phosphate Glass Melts and Phosphate Glasses," Glastech. Ber. Glass Sci. Technol., 71 187-92 (1998).

36. O. Claußen and C. Rüssel, "Votammetric Study of the Thermodynamics of the $\mathrm{Fe}^{3+} / \mathrm{Fe}^{2+}$ Equilibrium and the Self Diffusivity of Iron in Glasses with the Basic Composition 74 $\mathrm{SiO}_{2}(26-\mathrm{x}) \mathrm{Na}_{2} \mathrm{OxCaO}$," Phys. Chem. Glasses, 39 200-05 (1998).

37. S. Gerlach, O. Claußen, and C. Rüssel, "A Voltammetric 
Study on the Thermodynamics of the $\mathrm{Fe}^{3+} / \mathrm{Fe}^{2+}$-equilibrium in Alkali-lime-alumosilicate Melts," J. Non-Cryst. Solids, 248 92-8 (1999).

38. O. Claußen, S. Gerlach, and C. Rüssel, "Self-diffusivity of Polyvalent Ions in Silicate Liquids," J. Non-Cryst. Solids, 253 76-83 (1999).

39. A. Matthai, D. Ehrt, and C. Rüssel, "Voltammetric Investigations of the Redox Behaviour of $\mathrm{Fe}, \mathrm{Ni}, \mathrm{Co}$ and $\mathrm{Sn}$ Doped Glass Melts of $\mathrm{AR}^{\mathbb{R}}$ and $\mathrm{BK} 7^{\circledR}$ Type," Glastech. Ber. Glass Sci. Technol., 73 [2] 33-8 (2000).

40. G. von der Goenna and C. Rüssel, "Redox Equilibria of Polyvalent Elements in Binary $\mathrm{Na}_{2} \mathrm{OxSiO}_{2}$ Melts," Glastech. Ber, Glass Sci. Technol., 73 [4] 105-10 (2000).

41. C. Rüssel, "Electrochemical Study on the Redox Behavior of Selenium-containing Soda-lime-silica Melts," Glastech. Ber, Glass Sci. Technol., 74 [1] 1-5 (2001).

42. H. Jung, K. Kim, H. Kim, and Y. Kim, "Redox Equilibrium of Antimony by Square Wave Voltammetry Method in CRT Display Glass Melts," J. Korean Ceram. Soc., 44 [1] 1-5 (2007).

43. K. Kim, H. Kim, and Y. Kim, "Square Wave Voltammetry in Cathode Ray Tube Glass Melt Containing Different Polyvalent Ions(in Korean)," J. Korean Ceram. Soc., 44 [6] 297-302 (2007).

44. K. Kim, H. Kim, and J. Kim, "Behavior of Oxygen Equilibrium Pressure in CRT Display Glass Melts Doped with Sb and Ce Ions from the Viewpoint of Fining," J. Korean Ceram. Soc., 44 [8] 419-23 (2007).

45. K. Kim and Y. Kim, "Voltammetric Approach to Redox Behavior of Various Elements in Cathode Ray Tube Glass Melts," J. Non-Cryst. Solids, 354 [2-9] 553-57 (2008).

46. K. Kim, Y. Kim, H. Jung, and Y. Kim, "Voltammetric Approach to Redox Behavior of Various Elements in CRT Glass Melts," Proceedings of the XI International Confer- ence on the Physics of Non-Crystalline Solids, Rhodes, Greece, Oct. 25-Nov. 2 (2006).

47. K. Kim, H. Kim, and Y. Kim, "Redox Behavior and Diffusivity of Antimony and Cerium Ion in CRT Display Glass Melts, Proceedings of the XXI International Congress on Glass," Strasbourg, France July. 1-6 (2007).

48. K. Kim, "Fining of Flint Glass Melt Containing Blast Furnace Slag," J. Korean Ceram. Soc., 44 [11] 618-21 (2007).

49. K. Kim, H. Kim, and Y. Kim, "Redox Behavior of Sulfur in Flint Glass Melts by Square Wave Voltammetry, Proceedings of the XXI International Congress on Glass," Strasbourg, France July. 1-6 (2007).

50. K. Kim and H. Kim, "Electrochemical Approach in Plasma Display Panel Glass Melts Doped with Sulfate and Sulfide I. Oxygen Equilibrium Pressure," J. Korean Ceram. Soc., 45 [2] 90-3 (2008).

51. K. Kim and H. Kim, "Electrochemical Approach in Plasma Display Panel Glass Melts Doped with Sulfate and Sulfide II. Square Wave Voltammetry," J. Korean Ceram. Soc., 45 [7] 375-79 (2008).

52. K. Kim, "Iron Redox Equilibrium and Diffusivity in Mixed Alkali-alkaline Earth-silica Glass Melts," Ceram.-Silik., 55 [1] 54-8 (2011).

53. K. Kim and H. Kim, "Redox Behavior of Sn and S in Alkaline Earth Borosilicate Glass Melts with $1 \mathrm{~mol} \% \mathrm{Na}_{2} \mathrm{O}$," J. Korean Ceram. Soc., 46 [3] 271-74 (2009).

54. K. Kim, "Fining Behavior in Alkaline Earth Aluminoborosilicate Melts Doped with $\mathrm{As}_{2} \mathrm{O}_{5}$ and $\mathrm{SnO}_{2}$, J. Am. Ceram. Soc., 96 [3] 781-86 (2013).

55. K. Kim and K. Seo, "Influence of Nitrate on Fining and Sn Redox in Alkali free Aluminoborosilicate Glass Melts," Glass Technol.: Eur. J. Glass Sci. Technol. A, 54 165-68 (2013). 